Ekonomia - Wroclaw Economic Review 26/2 (2020)

Acta Universitatis Wratislaviensis

No 3992

https://doi.org/10.19195/2658-1310.26.2.5

\author{
Paweł Pisany \\ ORCID: 0000-0001-9665-8840 \\ Instytut Nauk Ekonomicznych Polskiej Akademii Nauk \\ ppisany@inepan.pl
}

\title{
Wsparcie rozwoju rynku obligacji korporacyjnych w wybranych gospodarkach azjatyckich po 1997 roku* $^{*}$
}

Artykuł nadesłany: 25.02.2020; artykuł zaakceptowany: 25.05.2020

Kody klasyfikacji JEL: G10, G15, G18

Keywords: financial market, corporate bonds, Asia

\begin{abstract}
Fostering the development of the corporate bond market in selected Asian economies after 1997

The article contains an analysis of the initiatives aimed at supporting the development of the corporate bonds market in three Asian economies: South Korea, Malaysia, and Thailand. These countries, after difficult experiences from the 1997 crisis, undertook initiatives focused on the development of domestic debt financial markets, mainly corporate bonds denominated in local currency. Case studies of three Asian economies show that the sustainable development of domestic debt markets can be fostered, among others, by: a high level of creditor rights protection, increased market access for institutional investors, in particular domestic ones, regional economic integration, increased market transparency, functioning of the rating agencies - domestic and the presence of global ones, availability of ratings and raising financial awareness in society.
\end{abstract}

\section{Wstęp}

Ze względu na doświadczenia związane z kryzysem z 1997 roku oraz potrzebę rozwoju krajowych dłużnych rynków finansowych gospodarki azjatyckie podjęły wiele inicjatyw mających na celu wsparcie rozwoju rynku obligacji korpora-

* Badania przedstawione w artykule zostały sfinansowane w ramach grantu Narodowego Centrum Nauki (numer UMO-2015/17/N/HS4/02939). 
cyjnych nominowanych w walucie krajowej. Inicjatywy te można podzielić na: projekty o zasięgu krajowym, z których część jest przedmiotem zainteresowania w niniejszym artykule, oraz projekty zrealizowane w ramach współpracy regionalnej między państwami azjatyckimi.

Spośród przedsięwzięć polityki gospodarczej o zasięgu regionalnym największe znaczenie miały: powołanie wyspecjalizowanych funduszy w celu inwestowania w obligacje, to jest Asian Bond Funds (ABF 1 i 2), a także współpraca w ramach grupy krajów ASEAN (Association of South-East Asian Nations), w szczególności szeroki projekt regulacyjno-gospodarczy — ABMI (Asian Bond Market Initiative) obliczony na rozszerzenie bazy inwestorów oraz zwiększenie różnorodności emitentów na rynkach dłużnych.

Mizen i Tsoukasy (2014) wykazali w swoim badaniu pozytywną relację między uczestnictwem kraju w regionalnych inicjatywach polityczno-gospodarczych (ABF 1, 2 oraz $\mathrm{ABMI}$ ) a prawdopodobieństwem emisji papierów dłużnych przez przedsiębiorstwa (szacowany wzrost prawdopodobieństwa względem grupy kontrolnej na poziomie 0,06). Ponadto Bhattacharyay (2013) podkreśla, że w dekadzie po kryzysie azjatyckim (między 1998 a 2008 rokiem) całkowita kapitalizacja rynku obligacji w badanej przez niego grupie krajów azjatyckich ${ }^{1}$ wzrosła o $217,3 \%$; w przypadku obligacji skarbowych wzrost ten wyniósł $275,3 \%$, a dla obligacji korporacyjnych $65,7 \%$, co może sugerować, że podjęte działania (na poziomie krajowym i regionalnym) łącznie okazały się skuteczne.

Celem niniejszego opracowania jest analiza i ocena reform oraz inicjatyw polityki gospodarczej dotyczących rynku obligacji korporacyjnych w wybranych krajach azjatyckich: Korei Południowej, Malezji i Tajlandii oraz zaproponowanie na tej podstawie pewnych rekomendacji odnoszących się do rozwoju tego rynku w Polsce.

\section{Teoretyczny aspekt badań oraz metoda badawcza}

Badania nad uwarunkowaniami rozwoju rynku instrumentów dłużnych przedsiębiorstw są wielowątkowe i mocno zróżnicowane. Można jednak wyszczególnić trzy podstawowe nurty:

1. Modele teoretyczne oraz studia porównawcze nad systemami gospodarczymi: De Fiore, Uhlig (2014); Zivanovic (2017), Song, Thakor (2010); Allen, Gale (1995); Demirguc-Kunt, Levine (1999); Lai (2012). Celem tych badań jest instytucjonalna analiza komparatystyczna, czasem typologia systemów finansowych oraz dyskusja nad ścieżkami ewolucji systemów finansowych między różnymi modelami, w szczególności modelem bankowo-centrycznym a modelem

${ }^{1}$ Chińska Republika Ludowa, Hongkong, Indonezja, Malezja, Filipiny, Singapur, Tajlandia, Wietnam, Japonia, Korea Południowa.

Ekonomia - Wroclaw Economic Review 26/, 2020

(C) for this edition by CNS 
opartym na rynkach finansowych. Spośród wyszczególnionych tu trzech kategorii badań pierwsza ma charakter najbardziej teoretyczny.

2. Badania i raporty związane ze wsparciem rozwoju rynku obligacji korporacyjnych w wybranych gospodarkach: Herring, Chatusripitak (2000); Hale (2007); Chang, Fernández i Gulan (2016); Noland (2005); Komisja Europejska (2017); Międzynarodowy Fundusz Walutowy (2005); International Capital Market Association (2016); Espenilla Jr. (2006); Amstad et al. (2016); Park (2016). Część z tych prac dotyczy szerokiej grupy krajów i prezentuje wybrane doświadczenia międzynarodowe z różnych regionów, co może być postrzegane jako zaleta. Wydaje się jednak, że warto rozwijać także bardziej szczegółowe studia przypadków dotyczące tylko wybranych rynków, podobnie do Noland (2005) czy Espenilla Jr. (2006).

3. Ilościowe badania empiryczne dotyczące azjatyckich rynków wschodzących: Eichengreen, Luengnaruemitchai (2004); Bhattacharyay (2013): Bae (2012); Smaoui et al. (2017); Burger, Warnock (2006); Burger et al. (2010); Burger et al. (2015). Badania te obejmują zawsze szeroką gamę krajów i mają charakter ilościowy, najczęściej są oparte na modelach panelowych wyjaśniających zmiany miar wielkości rynku obligacji (przeważnie wartość niezapadłych obligacji pozostających w obrocie) w ciągu około 20 lat. Aspekty trudno kwantyfikowalne, a mogące mieć wpływ na poziom rozwoju rynków dłużnych są najczęściej w tego rodzaju badaniach pomijane.

Niniejsza publikacja nawiązuje przede wszystkim do drugiej kategorii badań, choć zawiera także elementy komparatystyczne. Analiza wymienionych nurtów badań nad uwarunkowaniami rozwoju rynków obligacji korporacyjnych wskazuje, że ciągle pozostaje miejsce na jakościowe pogłębione studia nad wybranymi rynkami obligacji korporacyjnych o ciekawej historii, które mogą przynieść rezultaty w postaci rekomendacji dla praktyki gospodarczej w Polsce.

W ramach prac nad artykułem przeprowadzono studia literaturowe z uwzględnieniem pozycji naukowych oraz raportów rynkowych i opracowań dotyczących polityki gospodarczej. Na podstawie studiów przypadków porównano doświadczenia trzech wybranych gospodarek oraz przedstawiono wnioski.

\section{Projekty wsparcia rozwoju rynków dłużnych papierów przedsiębiorstw nominowanych w walutach krajowych w wybranych gospodarkach azjatyckich}

\subsection{Studium przypadku - wnioski z analizy Korei Południowej}

Lai (2012) wskazuje, że system finansowy w Korei Południowej po 1997 roku zaczął ewoluować z sytemu bankowo-centrycznego w kierunku systemu opartego 
na rynkach finansowych. Lai (2012) posługuje się na określenie takich systemów pojęciem LME — Liberal Market Economies. Przed kryzysem 1997 roku rynek instrumentów dłużnych przedsiębiorstw w Korei Południowej praktycznie nie istniał, by po siedmiu latach, w 2004 roku, jego wartość sięgała już 40\% PKB (na podstawie danych Banku Światowego oraz Asian Bonds Online).

Po 1997 roku władze koreańskie zdecydowały o zwiększeniu poziomu otwarcia kraju na inwestycje zagraniczne poprzez rynek kapitałowy. Początkiem działań w tym zakresie było uchwalenie Foreign Investment Promotion Act (1998 rok). W ramach liberalizacji rynku kapitałowego zniesiono także ograniczenia $\mathrm{w}$ inwestowaniu w koreański rynek akcji oraz - co istotne $\mathrm{z}$ punktu widzenia niniejszej analizy — w rynek obligacji rządowych, bonów skarbowych oraz obligacji przedsiębiorstw przez nierezydentów. Ponadto zniesiono część ograniczeń dla inwestorów zagranicznych na rynku instrumentów pochodnych (w tym opcji walutowych) (Rumiński, 2004).

Koreański rynek instrumentów dłużnych przedsiębiorstw jest interesującym przypadkiem zmian strukturalnych odnoszących się do parametrów i cech obligacji (Hwang, 2016). Publiczne plasowanie emisji obligacji przedsiębiorstw rozpoczęło się w Korei w 1972 roku. Wcześniej istniały jedynie emisje prywatne (do ograniczonej liczby konkretnie wskazanych inwestorów). Początkowo rynek obligacji był zdominowany przez emisje gwarantowane przez państwowe instytucje finansowe. Nabywcami emisji byli przeważnie duzi inwestorzy instytucjonalni (często również powiązani ze skarbem państwa). Po 1997 roku na skutek upadku niektórych emitentów i pogorszenia się sytuacji finansowej instytucji gwarantujących struktura rynku się zmieniła i zaczęły przeważać obligacje emitowane bez gwarancji strony trzeciej. Po globalnym kryzysie finansowym z 2008 roku powołano w Korei państwowy fundusz oferujący usługę gwarancji emisji obligacji - Korea Credit Guarantee Fund. Jego rola pozostaje jednak ograniczona. Nowy standard rynkowy oparty na emisjach niegwarantowanych doprowadził do tego, że rynek ograniczył się do emisji z najwyższymi ratingami, co w dalszej perspektywie może tworzyć barierę jego rozwoju jako narzędzia finansowania różnorodnych, w tym także innowacyjnych i tym samym obarczonych wyższym ryzykiem, projektów (Hwang, 2016; Amstad et al., 2016).

Obecnie emisje obligacji są regulowane przez koreańskiego nadzorcę finansowego. Wprowadzono przepisy wymagające odpowiedniej rejestracji emisji oraz szerokich ujawnień w ramach wymaganych dokumentów, między innymi prospektu. Zasadniczo emisje prywatne ${ }^{2}$ są obwarowane mniej restrykcyjnymi wymogami dotyczącymi ujawnień. Obligacje plasowane prywatnie nie mogą być jednak sprzedawane na rynku wtórym przez rok od emisji. Większość obligacji po emisjach publicznych jest kwotowana i staje się przedmiotem obrotu na giełdzie koreańskiej

${ }^{2}$ W Korei: emisje do konkretnie wskazanej grupy inwestorów liczącej nie więcej niż 50 podmiotów. 
(KRX). Giełda koreańska prowadzi w pełni zdigitalizowany system przekazywania informacji przez przedsiębiorstwa i ujawniania tych informacji inwestorom. System ujawnień w Korei opiera się na podwójnym obowiązku emitentów: do ujawnienia informacji przy emisji, a także $\mathrm{w}$ ramach funkcjonowania rynku wtórnego w cyklach kwartalnych lub półrocznych oraz przy okazji istotnych dla spółki wydarzeń. Wspieranie przejrzystości rynku w odniesieniu do transakcji pozagiełdowych (over-the-counter - OTC) jest trudniejsze niż w przypadku instrumentów kwotowanych na giełdzie. W przypadku Korei problem ten został zaadresowany przez inicjatywę samoregulacyjną. Dane dotyczące ceny i wolumenu transakcji instrumentami dłużnymi w Korei powinny być przekazywane do organizacji stworzonej przez podmioty rynkowe - Korea Financial Investment Association (KOFIA), która to publikuje te dane w czasie rzeczywistym. Inicjatywa ma na celu poprawę płynności wtórnego rynku OTC instrumentów dłużnych (Hwang, 2016).

Istotnym elementem wspierającym rozwój rynków dłużnych w Korei było także funkcjonowanie lokalnych agencji ratingowych. Rola agencji przed kryzysem z 1997 roku była istotnie ograniczona ze względu na rozpowszechnienie gwarancji emisji. Powodowało ono, że ocena ryzyka kredytowego emitenta oraz ocena jego projektu inwestycyjnego nie były najistotniejszymi aspektami warunkującymi ryzyko inwestycji w daną transzę obligacji. Inwestorzy postrzegali ryzyko zakupu danego instrumentu dłużnego przez pryzmat wiarygodności kredytowej gwaranta, a nie emitenta. Sytuacja zmieniła się po 1997 roku wraz z rozwojem rynku obligacji niegwarantowanych, który wiąże się z potrzebą profesjonalnej oceny ryzyka kredytowego danej transzy emisyjnej.

Obecnie rynek oceny kredytowej w Korei kształtują cztery agencje ratingowe. Trzy z nich, to jest Korea Investors Service (KIS), National Information \& Credit Evaluation (NICE) oraz Korea Ratings (KR), świadczą pełny zakres usług oceny kredytowej. Czwarta agencja - Seoul Credit Rating \& Information (SCI) ma charakter agencji wyspecjalizowanej i nadaje ratingi głównie instrumentom klasy ABS (Asset-Backed-Securities) oraz krótkoterminowym instrumentom dłużnym przedsiębiorstw.

Agencje ratingowe w Korei są własnością niebankowych instytucji finansowych oraz banków. Historia powstania każdej z trzech koreańskich uniwersalnych agencji ratingowych jest odmienna. NICE została założona jako inwestycja banków w 1986 roku. KR powstała w 1983 roku pod auspicjami Korea Development Bank $(\mathrm{KDB})^{3}$ - państwowego banku inwestycyjnego odpowiedzialnego za wdrażanie rozwojowej polityki gospodarczej w Korei. KIS natomiast została założona przez 70 koreańskich niebankowych instytucji finansowych w 1985 roku (Mitsui, 2009). Od momentu powstania agencje te ewoluowały, uzyskiwały kolejne regulacyjne koncesje i zgody na rozszerzanie działalności. Równolegle ewolucji ulegało podejście regulacyjne. Lokalne agencje koreańskie mogły rozwijać swój model bi-

3 http//:www.kdb.co.kr (dostęp: 1.06.2019). 
znesowy w kierunku uniwersalnej, szerokiej oferty ocen ratingowych, takich jak w przypadku agencji globalnych. Rozwój agencji ratingowych był w Korei wspierany poprzez ciągłe udoskonalanie właściwych aktów prawnych. Nowelizacje przepisów dotyczących agencji ratingowych miały miejsce w 2009 i 2013 roku. Ich celem było zwiększenie przejrzystości funkcjonowania agencji (Hwang, 2016; Mitsui, 2009). Cechą charakterystyczną rozwoju koreańskich agencji ratingowych była współpraca z globalnymi agencjami. KIS podpisała umowę partnerską z Moody’s Investors Service już w 1998 roku, a w 2007 roku Moody’s przejął większościowy pakiet udziałowy koreańskiej agencji. KR z kolei związała się z Fitch Ratings w 1999 roku. W 2007 roku Fitch przejął kontrolę nad kapitałem KR.

Równolegle podejmowano w Korei także inicjatywy polityki wewnętrznej mające na celu podniesienie jakości otoczenia instytucjonalnego, w którym funkcjonuje sektor finansowy. Jeśli chodzi o ład korporacyjny (corporate governance) $\mathrm{w}$ przedsiębiorstwach sektora realnego, zwiększono prawa akcjonariuszy mniejszościowych i zarządów. W szczególności wprowadzono w zarządach spótek obowiązek zasiadania tak zwanych outside directors, czyli dyrektorów niezwiązanych z głównym akcjonariuszem. $Z$ punktu widzenia potencjalnych dostarczycieli finansowania dłużnego, a zatem nabywców obligacji korporacyjnych danego przedsiębiorstwa, jest to zmiana pozytywna, gdyż podnosi przejrzystość zarządzania daną firmą. Ponadto zreformowano prawo upadłościowe i uzyskano poprawę efektywności egzekucji zobowiązań (Rumiński, 2004).

W przypadku Korei Południowej wskazane elementy pozwoliły na zwiększenie wartości emisji obligacji korporacyjnych mimo pewnych incydentalnych wydarzeń kryzysowych, które mogły zachwiać zaufaniem do instrumentów dłużnych. Najistotniejszym z takich wydarzeń był upadek Daewoo w lipcu 1999 roku po okresie dynamicznego finansowania projektów inwestycyjnych firmy poprzez emisję obligacji. Daewoo było trzecim pod względem wielkości konglomeratem przemysłowym w Korei Południowej (czebolem — chaebol). Jego upadek miał bezpośredni wpływ na sytuację inwestorów instytucjonalnych, szczególnie koreańskich ITC (investment trust companies). Straty funduszy na obligacjach Daewoo doprowadziły do skokowego wzrostu umorzeń jednostek (wycofania kapitału) przez inwestorów. Żądanie wycofania środków przez inwestorów wzmagało presję płynnościową i w konsekwencji dana instytucja finansowa była zmuszona do wyprzedaży aktywów. Taka wyprzedaż (fire sale) przyczyniała się do spadku ceny walorów na rynku, co oznaczało dalsze straty na posiadanych jeszcze instrumentach, umorzenia i ponownie rosnącą presję płynnościową. Ostatecznie ta negatywna spirala na rynku finansowym została zahamowana przez interwencję nadzorców. Po pierwsze, powołano fundusz (Bond Market Stabilisation Fund), na który składki wniosły głównie banki oraz ubezpieczyciele. Bezpośredni skup prowadzony przez fundusz pozwolił na zahamowanie spadków cen i wzrostów rentowności instrumentów dłużnych. W dalszej kolejności doprowadzono do zrealizowania (zaksięgowania strat) w bilansach firm ITC oraz zwiększono wymogi 
dotyczące transparentności. Wprowadzenie obowiązku rynkowej wyceny instrumentów w księgach inwestorów instytucjonalnych (mark-to-market) jest wiązane $\mathrm{w}$ literaturze z potrzebą odbudowy rynku instrumentów dłużnych po załamaniu związanym z upadkiem Daewoo (Lee, Kim, 2006).

\subsection{Studium przypadku - wnioski z analizy Malezji}

Lai (2012) wskazuje, że Malezja miała jedne z najlepszych regulacji rynku finansowego już przed kryzysem z 1997 roku. Podstawowe instytucje rynku kapitałowego były obecne, choć obligacje korporacyjne przed 1997 rokiem nie funkcjonowały jako istotny kanał pozyskiwania finansowania dłużnego dla przedsiębiorstw. Udział wartości obligacji przedsiębiorstw wyemitowanych w walutach krajowych w obrocie w PKB wzrósł w Malezji między 2000 a 2014 rokiem z około 35\% do 41\% (na podstawie danych Banku Światowego oraz Asian Bonds Online). Wzrost ten można w dużej mierze przypisać aktywności państwa (Lai, 2012). Rząd malezyjski realizuje politykę wobec rynków finansowych w ramach wieloletnich programów ${ }^{4}$, których celem jest podniesienie jakości otoczenia sektora finansowego oraz wsparcie pośredników i inwestorów instytucjonalnych. Wśród głównych założeń polityki rządowej po 2011 roku były: zwiększenie koncentracji w sektorze bankowym i rozwój większych pośredników finansowych, otwarcie na wiedzę, ale także na inwestycje zagraniczne realizowane poprzez rynek kapitałowy oraz transgraniczną współpracę gospodarczą. W 2005 roku otwarto na przykład możliwość świadczenia usług brokerskich przez nierezydentów. Wspierano także wprowadzenie do obrotu papierów wartościowych typu ABS (Asset Backed Securities) oraz MBS (Mortgage Backed Securities) w celu poprawienia poziomu wiedzy wśród inwestorów i tym samym zwiększenia poziomu płynności (bin Ibrahim, Adrian, 2006).

Rząd koordynował także inwestycje w rozwój infrastruktury teleinformatycznej potrzebnej do obrotu instrumentami finansowymi. W 1996 roku uruchomiono elektroniczny system zawierania transakcji Fully Automated System for Tendering (FAST). W 1999 roku wprowadzono elektroniczny system rejestracji instrumentów oraz rozliczeń transakcji — Real Time Gross Settlement Sysytem (RENTAS). Od 1997 roku funkcjonuje także elektroniczna baza danych, w której są publikowane dane dotyczące parametrów (przede wszystkim cen) transakcji obligacjami na rynku OTC - Bond Information and Dissemination System (BIDS) (bin Ibrahim, Adrian, 2006). Uproszczono także procedury emisyjne. W szczególności jeśli chodzi o rynek instrumentów dłużnych, procedura uzyskania zgód administracyjnych na emisję transzy obligacji danego przedsiębiorstwa uległa skróceniu do 14 dni (Lai, 2012).

W Malezji rynek ocen ratingowych kształtują dwie lokalne agencje: Rating Agency Malaysia Berhad (RAM) ${ }^{5}$ oraz Malaysian Rating Corporation Berhad

${ }^{4}$ Od 2001 roku — Capital Master Plan 1.

5 https://www.ram.com.my/about-us/ (dostęp: 1.06.2019). 
(MARC) $)^{6}$. Żadna z agencji nie ma akcjonariusza większościowego. Wśród akcjonariuszy znajdziemy instytucje finansowe — w pierwszej kolejności krajowe, ale także reprezentujące kapitał zagraniczny. Przed 2000 rokiem istniał wymóg uzyskania przez emisję obligacji korporacyjnych w Malezji ratingu na odpowiednio wysokim poziomie (co najmniej BBB). Przyczyniło się to do rozwoju krajowych agencji ratingowych oraz służyło budowaniu zaufania do rynku (bin Ibrahim, Adrian, 2006). Wymóg ratingu został utrzymany. Zniesiono natomiast minimalną wymaganą ocenę ratingową. W dalszej perspektywie budowanie dużego i płynnego rynku instrumentów dłużnych wymaga bowiem zróżnicowania oferty również na płaszczyźnie ryzyka kredytowego, oczywiście przy dostępności do przejrzystej informacji na jego temat (Hwang, 2016).

Z RAM są stowarzyszone dwie inne ważne dla rynku obligacji instytucje malezyjskie: Bond RAM Credit Information Sdn Bhd ${ }^{7}$ - platforma internetowa dostarczająca informacji biznesowych i kredytowych o przedsiębiorstwach malezyjskich, oraz Bond Pricing Agency Malaysia Sdn Bhd (BPA). BPA została powołana $\mathrm{z}$ inicjatywy regulatora rynku kapitałowego w 2006 roku jako niezależna agencja wyceny obligacji, której zadaniem było dostarczanie rynkowi we wczesnej fazie rozwoju (cechującemu się niskimi wolumenami obrotu) informacji cenowej. Agencja wśród swoich celów ma poprawę płynności rynku wtórnego obligacji. Dostarczanie informacji dotyczącej wyceny ma w założeniach pozwolić na rozwój aktywnych strategii inwestycyjnych (innych niż trzymanie instrumentu dłużnego do terminu zapadalności). Ponadto agencja ma między innymi zajmować się promocją innowacyjnych instrumentów dłużnych na rynku (Zain, 2017).

Cechą charakterystyczną malezyjskiego rynku instrumentów dłużnych przedsiębiorstw emitowanych w walucie krajowej jest to, że w przeważającej mierze składa się on z emisji obligacji zgodnych z prawem szariatu (Islamic Investment Certificates - Sukuk). W latach 2010-2017 60,8\% wartości nominalnej wyemitowanych obligacji przedsiębiorstw należało do segmentu Sukuk. Ponadto rynek malezyjski odpowiadał w 2017 roku za ponad 50\% wartości globalnego rynku Sukuk (Mohd Razlan, 2018). Poprzez zakup Sukuk inwestor dostarcza środki przedsiębiorstwu, ale nie otrzymuje wynagrodzenia w formie odsetek. Jego zyski są determinowane wartością wygenerowaną przez projekt biznesowy, który zdecydował się wesprzeć. W badaniach opartych na panelu przedsiębiorstw malezyjskich (Hisham Hanifa et al., 2015) wykazano, że emisje Sukuk są często wykorzystywane przez mniejsze, bardziej innowacyjne przedsiębiorstwa o większych perspektywach wzrostowych — prawdopodobnie ze względu na swoistą relację partnerską między inwestorem a przedsiębiorcą, która powstaje po zawar-

\footnotetext{
${ }^{6} \mathrm{https} / / /$ www.marc.com.my/index.php/about-marc/overview/introduction (dostęp: 1.06.2019).

7 https://www.ramcreditinfo.com.my/about-our-company/ (dostęp: 1.06.2019).
} 
ciu transakcji Sukuk. Duże przedsiębiorstwa mogące zaoferować zabezpieczenie długu częściej decydują się na emisje tradycyjnych obligacji.

\subsection{Studium przypadku — wnioski z analizy Tajlandii}

Tajlandia — w ocenie Lai (2012) — na tle innych już omówionych krajów odznacza się relatywnie najmniej zaawansowanym rozwojem rynków finansowych. W 2004 roku wartość wyemitowanych, niezapadłych dłużnych instrumentów przedsiębiorstw wyemitowanych w walutach krajowych osiągnęła około 7\% tajlandzkiego PKB, by w 2014 roku wynieść prawie 18\% (na podstawie danych Banku Światowego oraz Asian Bonds Online). Bezpośrednio przed wybuchem kryzysu azjatyckiego, przez dziewięć kolejnych lat: 1988-1997, Tajlandia prowadziła politykę nadwyżek budżetowych. Można więc uznać, że rynek obligacji przedsiębiorstw nie mógł się rozwijać, jako że nie było płynnego rynku obligacji skarbowych i tym samym informacji o wysokości stopy wolnej od ryzyka i niemożność utworzenia krzywej dochodowości koniecznej do wyceny instrumentów dłużnych innych niż skarbowe. Również później, czyli po kryzysie azjatyckim, rynek ten nie miałby pewnie szans rozwoju bez odpowiednich projektów polityki gospodarczej. Banki w Tajlandii nie były początkowo zainteresowane świadczeniem usług organizacji i plasowania emisji obligacji ze względu na zyski osiągane w swoim podstawowym modelu biznesowym, to jest poprzez udzielanie kredytów (Ruengvirayudh, Panyanukul, 2006).

Po 1997 roku władze Tajlandii podejmowały inicjatywy obliczone na zwiększenie popularności inwestycji w papiery dłużne z Domestic Bond Market Development Plan (2001-2004 oraz 2005-2014) na czele. W ramach tych inicjatyw postawiono sobie między innymi następujące cele: stworzenie infrastruktury teleinformatycznej umożliwiającej obrót obligacjami, edukowanie inwestorów detalicznych, ale przede wszystkim zorganizowanie efektywnych emisji obligacji skarbowych (poprawa systemu aukcyjnego) w celu stworzenia krzywej odniesienia dla wycen obligacji sektora prywatnego. Ten ostatni cel został już osiągnięty (Ruengvirayudh, Panyanukul, 2006; Phutthitada, 2017; Amstad et al., 2016).

Zainwestowano również $\mathrm{w}$ infrastrukturę rynkową, między innymi powstały izba rozliczeniowa oraz platforma handlu instrumentami dłużnymi. Od 2004 roku w Tajlandii funkcjonuje platforma elektronicznego obrotu obligacjami korporacyjnymi notowanymi na giełdzie - Bond Electronic Exchange (BEX). Rynek obligacji podlega w Tajlandii nadzorowi sprawowanemu przez odrębny organ, to jest Securities and Exchange Commission. Pod patronatem regulatora powstała także samoregulacyjna organizacja rynkowa - Thai Bond Market Association (ThaiBMA), która prowadzi działalność informacyjną, promocyjną oraz uczestniczy w wypracowywaniu standardów i dobrych praktyk rynkowych. Pełni ona ważną funkcję w zapewnianiu płynności na rynku wtórnym poprzez udostępnia- 
nie informacji. Do ThaiBMA są raportowane transakcje obligacjami zawierane zarówno na rynku giełdowym, jak i OTC. Instytucja natomiast przygotowuje na podstawie spływających danych dzienne raporty rynkowe z informacjami dotyczącymi przede wszystkim cen oraz wolumenów transakcji rynkowych (ASEAN, 2012) (Ruengvirayudh, Panyanukul, 2006).

Na rynku oceny ryzyka kredytowego w Tajlandii najważniejszą rolę odgrywają dwie agencje: TRIS Rating Co., Limited ${ }^{8}$ oraz Fitch Ratings (Thailand) Limited ${ }^{9}$. TRIS Rating Co., Limited (wcześniej Thai Ratings and Information Services Co., Limited) została założona w 1993 roku jako wspólny projekt ministerstwa finansów, banku centralnego z udziałem sektora prywatnego (Okuda, 2010). Od 2016 roku TRIS Ratings Co., Limited funkcjonuje w ramach partnerstwa z globalną agencją ratingową S\&P, która posiada 49\% udziałów we wspólnym przedsiębiorstwie. Druga z wymienionych agencji — Fitch Ratings (Thailand) Limited rozpoczęła działalność w Tajlandii w 2001 roku. Do udziałowców, którzy powołali agencję, należały Fitch Ratings Limited z Wielkiej Brytanii oraz inwestorzy instytucjonalni z Tajlandii (fundusz emerytalny, ubezpieczyciele oraz firmy zarządzające funduszami inwestycyjnymi). Fitch Ratings Limited jest największym udziałowcem (49,9\% kapitału).

Wydaje się, że podstawowe zaplecze infrastrukturalne rozwoju obligacji korporacyjnych w Tajlandii już istnieje. Na obecnym etapie rozwoju rynku obligacji przedsiębiorstw w Tajlandii kluczowe będą kwestie poprawy jakości instytucjonalnej i udoskonalenia otoczenia prawnego (między innymi zwiększenie ochrony praw wierzycieli), czyli działania obliczone na zwiększenie zaangażowania inwestorów instytucjonalnych (zarówno krajowych, jak i zagranicznych) na tym rynku i w dalszej kolejności na rozwój emisji publicznych skierowanych również do szerokiego grona inwestorów indywidualnych.

Przy okazji przedstawionej tu analizy na odnotowanie zasługują także projekty realizowane w ramach współpracy regionalnej między krajami azjatyckimi. Spośród przedsięwzięć polityki gospodarczej o zasięgu regionalnym największe znaczenie miały: powołanie wyspecjalizowanych funduszy w celu inwestowania w obligacje, to jest ABF 1 i 2, a także współpraca w ramach grupy krajów ASEAN ${ }^{10}$ (Association of South-East Asian Nations), w szczególności szeroki projekt polityczno-gospodarczy — ABMI (Asian Bond Market Initiative).

Pozytywny wpływ ABF 1, ABF 2 oraz ABMI na wielkość oraz płynność rynków obligacji przedsiębiorstw w krajach azjatyckich potwierdzają badania. Mizen i Tsoukasy (2014) oszacowali wzrost prawdopodobieństwa emisji papierów dłużnych przez przedsiębiorstwa $\mathrm{z}$ kraju uczestniczącego $\mathrm{w}$ wymienionych projektach na 0,06 .

${ }^{8}$ https://www.trisrating.com/about-us/company/ (dostęp: 1.06.2019).

9 https://www.fitchratings.com/site/thailand (dostęp: 1.06.2019).

10 Brunei, Kambodża, Indonezja, Laos, Malezja, Mianma, Filipiny, Singapur, Tajlandia, Wietnam (ASEAN) we współpracy z Chinami, Japonią oraz Koreą Południową (ASEAN + 3). 


\section{Wnioski i rekomendacje dla rozwoju rynku w Polsce}

Wyniki prac badawczych nad doświadczeniami gospodarek azjatyckich mogą w pewnym zakresie stanowić podstawę refleksji nad rekomendacjami dla polskiego rynku obligacji korporacyjnych. Zaprezentowane dalej rekomendacje nie tworzą kompleksowej strategii rozwoju rynku obligacji korporacyjnych w Polsce. Wypracowanie takiej strategii wymagałoby analizy doświadczeń liczniejszej grupy krajów niż tylko wybrane gospodarki azjatyckie. Kolejne punkty przedstawiają natomiast syntetycznie praktyczny wymiar podjętej $\mathrm{w}$ artykule pracy badawczej.

- Działania skierowane na ochronę praw wierzyciela

Działania te należy odnosić nie tylko do aktywności legislacyjnej, ale przede wszystkim do efektywności procedur w praktyce obrotu gospodarczego. Zgodnie z Globalnym Indeksem Konkurencyjności przygotowywanym w ramach prac World Economic Forum (Schwab, 2018) polska gospodarka znajduje się na 39. miejscu na świecie w kwestii konkurencyjności. Globalny Indeks Konkurencyjności składa się z 12 filarów. W przypadku Polski filar określony jako „Instytucje” należy do dwóch najniżej ocenionych obszarów mających wpływ na konkurencyjność polskiej gospodarki. W ramach tego obszaru do największych problemów zalicza się: efektywność regulacji dotyczących prowadzenia sporów między przedsiębiorstwami (106. miejsce), a także efektywność procedury zaskarżania decyzji administracyjnych (118. miejsce). Wydaje się zatem, że podniesienie rzeczywistego poziomu ochrony praw wierzyciela w Polsce wymagałoby poprawy między innymi w tych obszarach.

- Wsparcie strony popytowej rynku poprzez umożliwienie aktywności krajowych inwestorów instytucjonalnych na rynku obligacji korporacyjnych

Rozwój rynku instrumentów dłużnych nominowanych w walucie krajowej będzie możliwy, jeśli nastąpi równoległy rozwój komplementarnych składowych systemu finansowego, takich jak na przykład krajowe fundusze emerytalne, fundusze inwestycyjne oraz ubezpieczyciele, czyli inwestorzy instytucjonalni charakteryzujący się długoterminowymi strategiami inwestycyjnymi, przy odpowiednio szerokim zakresie możliwości inwestycyjnych wyznaczonych przez regulacje.

- Aktywne uczestnictwo Polski w kształtowaniu reform rynku papierów dłużnych w ramach Europejskiej Unii Rynków Kapitałowych

Regionalna integracja gospodarcza (nieobejmująca na obecnym etapie integracji walutowej) może być traktowana jako przewaga gospodarki polskiej nad gospodarkami azjatyckimi, jeśli chodzi o rozwój rynków finansowych. Otwiera 
bowiem szanse na funkcjonowanie w ramach jednolitego rynku kapitałowego, co oznacza dostęp do szerokiego grona inwestorów ${ }^{11}$.

- Zwiększanie przejrzystości rynku bez nadmiernego wzrostu obciążeń formalnych, szczególnie w stosunku do małych i średnich przedsiębiorstw zainteresowanych emisją obligacji

Władze koreańskie po upadku Daewoo i kryzysie zaufania wobec rynku obligacji prowadziły $\mathrm{w}$ dalekiej perspektywie politykę zwiększania transparentności rynku dłużnego. Niewywiązanie się ze zobowiązań wynikających z emisji obligacji przez spółkę GetBack S.A. w Polsce również jest wskazywane jako źródło spadku zaufania do rynków dłużnych (Szweda, 2018), choć oczywiście skala szoku jest w Polsce znacznie mniejsza, niż gdy w Korei upadł jeden z największych czeboli bardzo finansujący się na rynku dłużnym. $Z$ perspektywy zwiększania przejrzystości rynku należy wesprzeć inicjatywy dążące do rynkowej wyceny papierów dłużnych w portfelach funduszy inwestycyjnych. Może to uchronić rynek przed nagłymi korektami wyceny i w konsekwencji falami żądań umorzeń jednostek otwartych funduszy. Jednocześnie w analizach eksperckich łączy się ten postulat z innym rozwiązaniem, to jest umożliwieniem handlu obligacjami po dacie ich wykupu (Szweda, 2018a). W tym kontekście zasadne wydaje się wprowadzenie rozszerzonego obowiązku dematerializacji oraz rejestracji emisji obligacji.

- Powołanie ze wsparciem instytucji publicznych krajowej agencji ratingowej z misją dostarczania ratingów małym i średnim przedsiębiorcom

Kraje azjatyckie często wspierały powstawanie lokalnych agencji ratingowych. Idea uzupełnienia polskiego sektora agencji ratingowych o kolejną agencję powołaną ze wsparciem instytucji publicznych jest słuszna. Agencja ta powinna mieć specyficzny profil. Jej zadaniem powinno być dostarczanie ocen ratingowych małym i średnim przedsiębiorstwom, które nie są w stanie ponieść rynkowego kosztu takiej oceny. Przykład gospodarek azjatyckich, takich jak Korea Południowa czy Malezja, pokazuje, że powszechność dostępu do usług ratingowych intensywnie wspiera rozwój rynków dłużnych.

Wyzwaniem jest natomiast dostarczenie ratingów szerokiej gamie emisji, w tym przedsiębiorstwom o różnym poziomie ryzyka kredytowego, zarówno bardzo wiarygodnym, jak i podejmującym przedsięwzięcia bardziej ryzykowne. Rynek obligacji korporacyjnych może bowiem dostarczać finansowania innowacyjnym projektom małych i średnich przedsiębiorstw. Zróżnicowana pod względem ryzyka kredytowego oferta jest naturalną konsekwencją rozwoju tego rynku i wypełniania przez obligacje funkcji finansowania innowacyjnych projektów. W Malezji oraz Korei Południowej niestosowanie emisji o niższych ratingach jest

${ }^{11}$ Lista na podstawie rezultatów prac grupy roboczej: Expert Group on Corporate Bond Markets Liquidity set up działającej przy Komisji Europejskiej w ramach prac wspierających budowę EURK. https://ec.europa.eu/info/sites/info/files/171120-corporate-bonds-report_en.pdf (dostęp: 1.06.2019). 
uznawany za barierę wejścia rynku na wyższy poziom rozwoju. W przypadku rozwijania rynku w tym kierunku kluczowa jest rola przejrzystości, a także ochrony praw wierzyciela i efektywności procedur windykacyjnych i upadłościowych.

Osobną kwestią związaną z powołaniem agencji ratingowej ze wsparciem publicznym jest jej ostateczny akcjonariat i forma działalności. W Azji lokalne agencje ratingowe są zróżnicowane, jeśli chodzi o strukturę właścicielską i historię powstania. Wydaje się, że z punktu widzenia standardów funkcjonowania agencja ratingowa powinna być organizacyjnie odseparowana od innych instytucji rynku kapitałowego, szczególnie prowadzących obrót giełdowy i pozagiełdowy, a także władz publicznych. W ten sposób można uniknąć ryzyka reputacyjnego dla najważniejszych instytucji rynku kapitałowego w Polsce, które mogłoby się zmaterializować wraz z potencjalnymi błędami w ocenie prowadzonej przez agencję ratingową. Ład korporacyjny agencji ratingowej powinien zapewniać zarządowi mocną pozycję wynikającą między innymi z procedury powołania. Osobnym wyzwaniem pozostaje zapewnienie odpowiedniego zaplecza eksperckiego, szerokich kompetencji merytorycznych oraz zbudowanie prestiżu i zaufania do ocen nowej agencji szczególnie wśród inwestorów instytucjonalnych. Lokalne agencje ratingowe w Malezji oraz część agencji koreańskich i tajlandzkich funkcjonują jako projekty biznesowe o złożonym akcjonariacie z udziałem podmiotów państwowych oraz prywatnych, to jest instytucji finansowych — głównie krajowych, ale także zagranicznych.

- Wprowadzenie obowiązku uzyskania ratingu przez emitenta bez wyznaczania minimalnego poziomu ratingu

Wraz z powołaniem nowej agencji ratingowej sprofilowanej na dostarczanie ocen małym i średnim przedsiębiorstwom można rozważyć wprowadzenie obowiązkowego ratingu przy emisjach przeprowadzanych w PLN. Przykład Malezji pokazuje, że nie powinno to wiązać się z ustaleniem minimalnego wymaganego ratingu. W dalszej perspektywie takie wymogi mogą bowiem ograniczać rozwój rynków dłużnych.

- Stworzenie portalu informacyjnego o rynku na wzór Asian Bonds Online

W ramach inicjatyw o charakterze rynkowym na poziomie UE można zapoczątkować funkcjonowanie portalu internetowego na wzór Asian Bonds Online, który zawierałby dane rynkowe, raporty, omówienie kwestii regulacyjnych związanych z emisjami oraz inwestowaniem na rynku dłużnym poszczególnych państw członkowskich UE.

- Na gruncie krajowym wsparcie finansowe oraz organizacyjne powinno być kierowane do inicjatyw obliczonych na podniesienie świadomości i wiedzy finansowej w społeczeństwie

Jest to potencjalny obszar współpracy władz publicznych i sektora prywatnego. 


\section{Bibliografia}

Allen, F., Gale, D. (1995). A welfare comparison of intermediaries and financial markets in Germany and the US. European Economic Review, 39, 179-209.

Amstad, M., Kong, S., Packer, F., Remolona, E. (2016). A spare tire for capital markets: Fostering corporate bond market in Asia. Bank for International Settlements Working Paper Series, 85, $1-38$.

ASEAN (2012). Thailand. Bond Market Guide. ASEAN + 3 Bond Market Guide.

Bae, K.-H. (2012). Determinants of local currency bonds and foreign holdings: Implications for bond market development in the People's Republic of China. ADB Working Paper Series, $1-79$.

Bhattacharyay, B.N. (2013). Determinants of bond market development in Asia. Journal of Asian Economics, 24, 124-137.

Burger, J.D., Warnock, F.E. (2006). Local currency bond markets. IMF Staff Papers, 53, 133-146.

Burger, J.D., Warnock, F.E., Cacdac Warnock, V. (2010). Emerging local currency bond markets. NBER Working Papers, 16249, 1-40.

Burger, J.D., Warnock, F.E., Cacdac Warnock, V. (2015). Bond Market Development in Developing Asia. ADB Economics Working Paper Series, 448, 1-20.

Chan, E., Chui, M., Packer, F., Remolona, E. (2011). Local currency bond markets and the Asian Bond Fund 2 Initiative. Raport Banku Rozliczeń Międzynarodowych. Bank of International Settlements, 1-34.

Chang, R., Fernández, A., Gulan, A. (2016). Bond Finance, Bank Credit, and Aggregate Fluctuations in an Open Economy. NBER Working Paper, 22377, 1-53.

De Fiore, F., Uhlig, H. (2014). Corporate Debt Structure and the Financial Crisis. NBER Working Paper, 20730, 1-35.

Demirguc-Kunt, A., Levine, R. (1999). Bank-based and market-based financial systems cross-country comparisons. World Bank Research Working Paper, WPS 2143.

Eichengreen, B., Luengnaruemitchai, P. (2004). Why doesn't Asia have bigger bond markets? NBER Working Paper, 10576, 1-44.

Espenilla Jr., N.A. (2006). The corporate bond market in the Philippines. BIS Papers, 26, Part 18, $1-10$.

Hale, G. (2007). Bonds or loans? The effect of macroeconomic fundamentals. The Economic Journal, 117, 516, 196-215.

Herring, R.J., Chatusripitak, N. (2000). The Case of the Missing Market: the Bond Market and Why It Matters for Financial Development. The Asian Development Bank Institute / Wharton Seminar on Financial Structure for Sustainable Development in Post-Crisis Asia, 26 maja 2010. Tokyo.

Hisham Hanifa, M., Mansur, M., Obiyathulla I.,B. (2015). Why do issuers issue Sukuk or conventional bond? Evidence from Malaysian listed firms using partial adjustment models. Pacific-Basin Finance Journal, 34, 233-252.

Hwang, S. (2016). Corporate Bond Market in Asia and Pacific and Its Role in Financing for Development. Discussion Paper. First High-Level Follow-up Dialogue on Financing for Development in Asia and the Pacific, 30-31 marca 2016. Incheon. Republic of Korea.

bin Ibrahim, M., Adrian, W. (2006). The corporate bond market in Malaysia. BIS Papers, 26, 114 128.

International Capital Market Association (2016). Remaking the corporate bond market. Zurich. ICMA.

Komisja Europejska (2017). Improving European Corporate Bond Markets. Report from the Commission Expert Group on Corporate Bonds.

Lai, J. (2012). Financial Crisis and Institutional Change in East Asia. London: Palgrave Macmillan.

Ekonomia - Wroclaw Economic Review 26/, 2020

(C) for this edition by CNS 
Lee, M.-J., Kim, S.-H. (2006). Developing the corporate bond market: the Korean experience. BIS Papers, 26.

Ma, G., Remolona, E.M. (2005). Opening markets through a regional bond fund: lessons from ABF 2. Bank of International Settlements Quarterly Review, 1-12.

Międzynarodowy Fundusz Walutowy (2005). Global Financial Stability Report (chapter IV).

Mitsui, H. (2009). The Finance in the Capital Market and Credit Rating in Korea. College of Economics, Nihon University, 1-28.

Mizen, P., Tsoukasy, S. (2014). What promotes greater use of the corporate bond market? A study of the issuance behaviour of firms in Asia. Oxford Economic Papers, 66, 227-253.

Mohd Razlan, M. (2018). Malaysian Bond \& Sukuk Market. Showcasing Asian Bond Markets: Opportunities And Risks. An ACRAA Conference In Cooperation With Asian Bankers Association Wyndham Grand Hotel, 23 kwietnia 2018. Manama. Bahrain.

Noland, M. (2005). South Korea's Experience with International Capital Flows. NBER Working Paper, 11381, 1-70.

Okuda, H. (2010). Bond Market and Rating Agencies in Thailand. Hitotsubashi University WP, $1-17$.

Park, C.-Y. (2016). Developing Local Currency Bond Markets in Asia. ADB Economics Working Paper Series, 495, 1-28.

Phutthitada, T. (2017). Bond Market Development. Experience of Thailand. Workshop on Bond Market Development in Emerging East Asia, 11 sierpnia 2017. Yangon. Myanmar.

Ruengvirayudh, P., Panyanukul, S. (2006). The corporate bond market in Thailand. BIS Paper, 26, $152-160$.

Rumiński, M. (2004). Kryzys walutowy 1997 roku a restrukturyzacja sektora finansowego I sektora przedsiębiorstw w Korei Południowej. Materiały i Studia NBP, 174, 1-97.

Schwab, K. (2018). The Global Competitiveness Report 2017-2018. World Economic Forum.

Smaoui, H., Grandes, M., Akindele, A. (2017). The Determinants of Bond Market Development: Further Evidence from Emerging and Developed Countries. Emerging Markets Review, 148 167.

Song, F., Thakor, A.V. (2010). Financial System Architecture and the Co-evolution of Banks and Capital Markets. The Economic Journal, 120, 1021-1055.

Szweda, E. (2018a, września 24). Kolejne propozycje zmian prawnych na rynku obligacji, 1.12.2019, https://www.parkiet.com/Obligacje/309249990-Kolejne-propozycje-zmian-prawnych-na-rynku-obligacji.html.

Szweda, E. (2018, września 14). W tak złej kondycji rynek obligacji korporacyjnych nie byt od czasów niemowlęcych, 1.12.2019, https://www.analizy.pl/fundusze/wiadomosci/24312/w-takzlej-kondycji-rynek-obligacji-korporacyjnych-nie-byl-od-czasow-niemowlecych.html.

Zain, S. (2017). Malaysian Bond Market: Valuation and Information Infrastructure. Workshop on Bond Market Development in Emerging East Asia, 11-12 sierpnia 2017. Yangon, Myanma.

Zivanovic, J. (2017). Corporate Debt Composition and Business Cycles. Bank of Canada Staff Working Paper, 2019-5, 1-40.

Ekonomia - Wroclaw Economic Review 26/, 2020

(C) for this edition by CNS 